\title{
Pastoral care (Seelsorge) and spiritual care in Germany
}

\begin{tabular}{|c|c|}
\hline $\begin{array}{l}\text { Author: } \\
\text { Constanze Thi }\end{array}$ & erfelder $^{1,2}$ \\
\hline $\begin{array}{l}\text { Affiliations: } \\
\text { Department } \\
\text { Theology, Prac } \\
\text { Philipps Unive } \\
\text { Marburg, Ger }\end{array}$ & $\begin{array}{l}\text { ff Protestant } \\
\text { tical Theology, } \\
\text { rsity of } \\
\text { many }\end{array}$ \\
\hline $\begin{array}{l}\text { Department } \\
\text { Theology, Fac } \\
\text { Theology, Uni } \\
\text { Pretoria, Sout }\end{array}$ & $\begin{array}{l}\text { f Practical } \\
\text { lty of } \\
\text { /ersity of } \\
\text { Africa }\end{array}$ \\
\hline $\begin{array}{l}\text { Research Proj } \\
\text { Project Leade } \\
\text { Project Numb }\end{array}$ & $\begin{array}{l}\text { ct Registration: } \\
\text { r: Y. Dreyer (1) } \\
\text { er: } 2546930\end{array}$ \\
\hline $\begin{array}{l}\text { Description: } \\
\text { Prof. Dr Thierf } \\
\text { participating i } \\
\text { project, 'Gend } \\
\text { Practical Theo } \\
\text { Formation', di } \\
\text { Dr Yolanda Dr } \\
\text { Department o } \\
\text { Theology, Fact } \\
\text { University of F }\end{array}$ & $\begin{array}{l}\text { lder is } \\
\text { the research } \\
\text { er Studies and } \\
\text { logy Theory } \\
\text { ected by Prof. } \\
\text { eyer, } \\
\text { f Practical } \\
\text { lty of Theology, } \\
\text { retoria. }\end{array}$ \\
\hline $\begin{array}{l}\text { Correspondin } \\
\text { Constanze Thi } \\
\text { thierfec@mai } \\
\text { de }\end{array}$ & $\begin{array}{l}\text { author: } \\
\text { erfelder, } \\
\text { er.uni-marburg. }\end{array}$ \\
\hline $\begin{array}{l}\text { Dates: } \\
\text { Received: } 05 \\
\text { Accepted: } 05 \\
\text { Published: } 13\end{array}$ & $\begin{array}{l}\text { ept. } 2017 \\
\text { ept. } 2017 \\
\text { Nov. } 2017\end{array}$ \\
\hline $\begin{array}{l}\text { How to cite th } \\
\text { Thierfelder, C. } \\
\text { 'Pastoral care } \\
\text { spiritual care } \\
\text { HTS Teologies } \\
\text { Theological St } \\
\text { a4803. https:/ } \\
\text { 10.4102/hts.V }\end{array}$ & $\begin{array}{l}\text { is article: } \\
\text { 2017, } \\
\text { (Seelsorge) and } \\
\text { ' Germany', } \\
\text { Studies/ } \\
\text { udies 73(4), } \\
\text { /doi.org/ } \\
\text { 73i4.4803 }\end{array}$ \\
\hline $\begin{array}{l}\text { Copyright: } \\
\text { (c) 2017. The } \\
\text { Licensee: AOS } \\
\text { is licensed un } \\
\text { Creative Comr } \\
\text { Attribution Lic }\end{array}$ & $\begin{array}{l}\text { uthors. } \\
\text { S. This work } \\
\text { ler the } \\
\text { nons } \\
\text { ense. }\end{array}$ \\
\hline Read onlin & \\
\hline 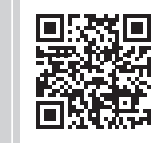 & $\begin{array}{l}\text { Scan this QR } \\
\text { code with your } \\
\text { smart phone or } \\
\text { mobile device } \\
\text { to read online. }\end{array}$ \\
\hline
\end{tabular}

In German-speaking countries the term spiritual care becomes more and more popular, not only in the realm of palliative care but also amongst pastoral care takers. In this article I argue that favouring of the term 'spiritual care' is not only a tribute to the changing situation in German-speaking countries, but also a way pastoral care takers want to deal with the challenges they face in a secular, multicultural society. I will discuss whether the use of the term 'spiritual care' is a way to 'lower the profile' of pastoral care and trying to be less explicit about the institution the pastors represent and the worldview they hold. This might look like an easy escape but does not foster the interaction in a multi-cultural space.

\section{Introduction}

There is a broad discussion in German-speaking countries whether the traditional term 'Seelsorge' / pastoral care should rather be replaced by the term spiritual care. In the following article I will discuss the concept of spiritual care and its reception in German-speaking countries and the contemporary situation where this discussion takes place.

I want to show that pastoral care in Germany has to face several challenges. The idea to change the name from 'Seelsorge' [care of the soul, soul-care] ${ }^{1}$ to pastoral care is a reaction to these challenges. In order to understand if this is a helpful solution, I will talk about the situation in German-speaking countries and about the challenge these countries face. I will also use an outside perspective, the view of psychotherapists, on the way they deal with religion in order to define the problem and to look for a new way to deal with a plurality of worldviews in German-speaking countries. That may help pastoral care takers whom find themselves among many who work in the multifaceted field of spirituality.

\section{The concept of spiritual care}

It is not easy to describe the meaning of 'spiritual care'. Doris Nauer (2015:14-19) lists no less than 17 ways to understand 'spiritual care'. The easiest way to grasp the meaning of spiritual care is to go back to the beginning.

The British nurse, social worker and doctor Sicily Saunders (1918-2005) started 'palliative care' as a critique to the way medical care dealt with patients who suffered from terminal illnesses. Saunders criticised the idea of medical care that you have to fight against any disease to the bitter end. Instead it became important to Saunders to help the dying patient not to suffer but to die with as few pains as possible and in a dignified way. When working with the dying patients and their families, she realised also that it is important to also care for their spiritual needs. Having religious affiliations or not, dying patients and their families are troubled by questions of guilt and shame, of the meaning of life, on shortcomings and sin, questions that medical care could not answer.

Sicily Saunders was an Anglican woman and all her efforts in palliative care are deeply rooted in her Christian faith, without being driven by a missionary impetus. Her key concept was to enhance the quality of life of the dying patient. Total pain at the end of life that encompasses the physical, psychological, social and spiritual dimension should be diminished as much as possible. To give 'total care' or 'rounded care' as she called it, a multidisciplinary team needed to care for the needs in all the different dimensions. The spiritual dimension needed special attention, separately and in context with the other fields (Saunders 1988). The development of 'palliative

1.In German-speaking countries, the term Seelsorge, that is soul care, is mostly used for Christian pastoral care. The term 'soul' itself belongs to a wider context. You find it in different contexts and languages. In the biblical context, the Hebrew term for soul is näfäsch, meaning literally throat, in greek it is psyche, which represents the third part of humans, besides body and mind. These contexts of meaning are all present in the German term Seelsorge. Conf. for example: Michael Klessmann (2008). 


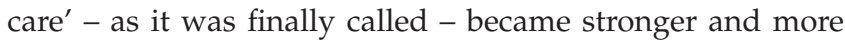
relevant when the medical faculty discovered this new field. At the same time, 'palliative medical care' needed scientific evidence to proof that a dying patient needed not only medical, psychological and social support, but that dying patients have spiritual needs as well. So they fostered empirical research to gather data that taking care of their spiritual needs enhances the quality of life of dying persons.

In the United States, quantitative and qualitative research on the relations of religion and health were already widely established. The 'Faith Factor Research' in palliative care became another important field of empirical research. In 2009, medical doctor Christina Puchalsky and other researchers summarised (Puchalsky et al. 2009):

Surveys have demonstrated that spirituality is a patient need, that it affects health care decision making and that spirituality affects health care outcomes including quality of life. (p. 885)

Influenced by the medical frame of reference, Puchalsky and others defined and treated spiritual need as any other physical illness. They developed ways to take a spiritual anamnesis, to find a diagnosis and to develop a treatment plan. Spiritual need or spiritual pain was considered to be one more need of the patient that the medical health care system should and could find a treatment for. It may be important to treat 'faith factor' in a quasi-medical way in order to be able to integrate it in the medical health care system. Only then medical health care institutions, like hospitals, homes for the elderly and palliative care units will see it as an important factor that justifies spending resources of personnel and time on it. In this way, spiritual care becomes an economic factor. It takes part in the economic mechanisms of input and outcome and in all the other rules of the world of economics. In Germany and other European countries, where Christian churches still play an important role in society, the situation of pastoral care in public institutions is quite different from the situation in the United States and many other countries.

\section{Pastoral care in public institutions in Germany and other European countries}

In Germany, like in many European countries, hospitals and homes for the elderly were often founded by, and run by the churches from the Middle Ages, on and off until today. Even when the state or private investors took over protestant and catholic churches, pastoral care in these institutions was still provided. Full-time and part-time chaplains and pastors employed by the churches provided pastoral care in hospitals and homes for the elderly, but also in prisons, on the basis of a contract between the state and the churches (Staatskirchenvertrag).

Pastors and chaplains are thus not part of the organisation of the institution. They provide support not only for the patients but also for all people working in the institution. As pastors they have special rights, for example, the right to refuse to give evidence before legal courts and they are bound by the seal of confession. These privileges give them a special credibility and generate trust, not only in prison but wherever they work. These privileges were granted when the Christian churches held the absolute majority concerning institutionalised religion. Other religions and their institutions do not take part in this contract between state and church, nor in the privileges that are granted.

\section{Changes and challenges in pastoral care in Germany and German- speaking countries today}

As in many other European countries, Germany's society shows a growing plurality. Even if German politicians tried to deny it over a long time: Germany is an immigration country. Immigration started with Italian and Turkish workers invited to work in Germany when the German economy needed working power in the 1960's and 1970's, in the time of the 'Wirtschaftswunder'. It wasn't planned for these workers to stay, but only to help out for a time and then go back to their home countries. But they stayed. Later boat people from Vietnam, refugees from the Balkan wars and after the falling of the Iron Wall, many people with German roots came from the Ukraine, from Siberia and from other parts of the former Soviet Union to settle in Germany. The refugees of the last two years from Syria, but also from Afghanistan, Iran, Irak and from many African countries, made it only more clear that Germany, like many other European countries, has changed. It is growing to become more and more diverse. Even in smaller cities and in the rural areas you can find people of many different color, and costumes of diverse shapes and colors belonging to different religions and religious affiliations. When, in 2010, the president (Bundespresident) of Germany, Christian Wulff, named the obvious 'Der Islam gehört zu Deutschland' [Islam is part of Germany], the comments were not altogether friendly. But one could hardly deny the obvious any longer. Looking at the number of people having no religious affiliation at all, you must add: People not religiously affiliated belong to Germany as well.

For pastoral care in hospitals and prisons, especially in the big cities, these changes became obvious much earlier than in the parishes of the rural areas. In big cities like Frankfurt, you find people of more than 50 nations with all their different religious affiliations. Many others have no religious affiliation at all. The pastoral care givers in hospitals and prisons belong mostly to one of the Christian denominations. There are only few Muslim (pastoral) care takers and no care takers with no religious affiliation at all, as some of the hospitals in the Netherlands provide. These two 'deficits' need to be examined separately.

2.Different empirical research organisations agree that in 2015 in Germany about $30 \%$ of the population were part of the Protestant Church, $30 \%$ wi Germany about $30 \%$ Church, $5 \%$ were Muslim and members of other religious organisations, with the rest not part of any religious organisation. Demographic changes in the Christian population (low number of births and high number of deaths) and growing immigration of mostly Muslim people, will change these numbers in the coming years. 


\section{Muslim 'pastoral' care}

There are several reasons why Muslim pastoral care is hardly ever available in German hospitals. Firstly, in Muslim tradition the function of 'pastoral care' does not exist in the same way as it does in Christian congregations. Traditionally, Muslim families cover the social part of 'pastoral care'. Family members attend to the sick member in hospital. They bring food, they talk to him or her and they do not leave the one in need alone. On the other hand, the Iman, the one knowledgeable in the way of the Coran, should be understood as he helps the ill person to interpret how to deal with the laws of the Coran, considering the given circumstances.

Today the traditional ways Muslim families live together in one place often do not work out any longer. Families are torn apart by migration or by moving away to study or to work. Specialised hospitals are far from where the families live. Dividing the responsibilities between care taking and religious guidance, does not work any longer.

At the same time, Muslims in Germany live in a society which is still shaped by Christian traditions. Many may have had experiences with Christian pastoral care that is available in hospitals. This may be one reason why people of Muslim faith want to be trained in 'pastoral care'. In Germany, several centers for Clinical Pastoral Education offer intercultural and interreligious training courses. In Frankfurt, the Center for Pastoral Care and Counseling of the Protestant Church in Hessen and Nassau offers intercultural and interreligious courses of CPE in collaboration with the Muslim organisation 'Salam e.V.'. These courses are an on-the-job training for pastoral care in hospitals. At the same time these courses of 6 weeks offer an opportunity for intercultural and interreligious communication, to find out about differences and communalities and to live together without brushing over the differences (Hess \& Nagel 2017). ${ }^{3}$

It is important to note that there is one prerequisite for people participating in this CPE course. The participants have to be affiliated with a distinct faith and they have to be knowledgeable in this faith and qualified for their task.

But what about patients and clients who are not affiliated with any religious group or belief?

\section{Pastoral care for people without religious affiliation}

Germany is one of the most secular countries in the world. This is especially true for the eastern part of Germany, the former DDR (German Democratic Republic) which was under the influence of the Soviet Union from 1945 to 1989. Under the socialistic regime, religion and religious affiliation were considered to be irrational and not compatible with a

3.In this documentation of one of these intercultural CPE COurses, Wilfred Hess and Bernat Nagel point out the important differences [Isamic 'Pastorl' [Islamic 'Pastoral' Care] and 'Seelsorge an Muslimen' [Pastoral Care with Muslims]. Pastoral care takers of different cultural and religious background should be able to give pastoral care to Muslims. But only people from Muslim background should give Islamic pastoral care, which is to give pastoral care based on Islamic theology. scientific worldview. In the Soviet Union, in Poland and in many other countries under the Soviet rule, Christian belief went into hiding and resurfaced after the end of the communist era. That was different after the end of the DDR. In many families there were no Christian traditions left after two generations of anti-Christian teachings and suppression.

In the western part of Germany secularisation processes set in, especially in the 70's and 80's, when the economic growth was strong and the belief in social advancement and individual success became very popular.

Even those who are still members of a Protestant or Catholic church often feel less and less connected to the church they pay membership taxes to. ${ }^{4}$ This is pictured in the title of the new empirical study on the membership in a Christian church that includes also studies on people who are not affiliated with a Christian church. It is the fifth membership survey ('V. Kirchenmitgliedschaftsstudie') and its title is 'Engagement und Indifferenz' (EKD 2015). This study points out that people who are not members of the church are not against religion but they see no reason why they should be members of a church. Religion is simply not part of their life and not part of the lives of most of the people around them.

The study shows that even when these people who are not affiliated with a church they are confronted with the existential crises, like diseases, loss or death, they may use what churches offer, but they hardly change their minds. For many members of the church, especially those working in and for the church, this is hard to take.

These people who lost interest or have only a fleeting interest in faith even if they are still members of the church, are a special challenge for pastors and they try to find new ways to deal with this phenomenon. This may be one of the reasons why the seemingly neutral term 'spiritual care' holds a special attraction for pastoral care takers in Germany.

\section{Promises and pitfalls of the term spiritual care in German-speaking countries}

In the following I want to discuss 'spiritual care' not as a practice but with regard to the mental images and concepts it evokes in German-speaking countries, especially when comparing it to the term 'Seelsorge' / pastoral care.

Firstly, we have to discern the multilayered meaning of 'Spiritualität/spirituell' in the German language. TraugottRoser (2007:269) sees two different lines of understanding at work:

- In Anglo-American tradition, 'spirituality' is not opposed to existing religious traditions like Catholic and Protestant faith or Muslim and Buddhist faith. It is rather a term to summarise all kinds of religious beliefs

4.In Germany the state draws in the church tax directly from the salary together with all the other taxes. The churches pay the state for this special service. 
and faiths. The perspective is rather on how to find a personal way of believing within these different religions. In a way 'spirituality' is in opposition to 'dogma', that is to the institutionalised forms of belief. Anglo-American understanding of spirituality I see in line with the search for 'The Living God' that Ana Maria Rizzuto (1979) described in her empirical study 'The Birth of the Living God'. In this psychoanalytical study she describes the development of faith of persons within specific religious traditions.

- The second understanding of the German term 'Spiritualität' is rooted in the French term 'Spiritualité' which is opposed to any form of institutionalised religion and especially to Christian forms of religion. It is rather a way of discovering the spirit in the world, turning away from emptied rituals of the church, discovering totally different ways of believing in nature, the body or the spirit in the world. It is a kind of counter reaction against the disenchantment of the world by enlightenment, and technological progress and cold reason. But it is also a reaction against churches and congregations where they tried to impose rituals, beliefs and norms in a rigid way that emptied church traditions of all meaning and ignored, and sometimes even humiliated, the individual believer and his needs.

In German language 'Spiritual Care' oscillates between the two ways of understanding the term 'Spiritualität'. If people are not well acquainted with Anglo American language and the way the term spirituality works in English, they tend to understand it in the French line of the word.

Doris Nauer (2015:38) sees it as an amazing development that the term spiritual care quickly became popular, not only in the realm of palliative care but also within the field of Christian pastoral care. She describes that in Anglo American, the term 'pastoral care' is already often replaced by the term 'spiritual care', which is considered more open and less linked to a certain confession or belief.

In Europe, the Netherlands plays a special part in that they are ahead of the other European countries. In the small but very diverse and very secular society, you can find developments that will sometimes happen a few years later in the rest of Europe. So, it is interesting to see what happens in Dutch hospitals regarding pastoral care. Dutch hospitals organise pastoral care/spiritual care independently from the churches. Since 1996, every patient in hospital is entitled to get 'GeestelijkeVerzorging', that is spiritual care according to their belief system. Firstly, it was required for these 'GeestelijkeVerzorgers' to have a degree in theology but later this was not required anymore. 'GeestelijkeVerzorgers' founded an organisation with five different sections for Christian, Jewish, Hindu, Muslim, and Humanistic belief systems. In 2013, a sixth section was opened for Ongebonden GeestelijkeVerzorgers. Spiritual care givers that are not affiliated with any organised form of religion are now equally accredited to give spiritual care in hospitals (Nauer 2015:40).
This development shows that 'spiritual' is not linked to any form of religion anymore. It developed into a free floating spirituality that is not rooted in any tradition, but more or less created by the spiritual care giver himself or herself, probably by assembling different pieces of other traditions in an eclectic way. What do the Christian care persons think about the terms of spiritual care and Seelsorge for themselves?

\section{Expectations and hopes connected to 'spiritual care' in German- speaking countries}

As I pointed out above, in German-speaking countries theologians use the term 'spiritual care' in two different ways. Some German-speaking authors use the term in an AngloAmerican way and do not see any problem when replacing the term Seelsorge/ pastoral care by the term spiritual care. For them the term spiritual care is a rather pragmatic way to broaden the horizon of pastoral care to include people of other non-Christian conviction into their care as well (Walther 2009:259-278). For them the term spiritual care says nothing about the care taker and his or her faith, nothing about his/ her education. It is simply an 'umbrella term' to describe people giving care and support for the soul of Christians and people of other faiths and beliefs.

On the other hand, a survey in German-speaking Switzerland showed that the majority of interviewed pastors see 'spirituality' as something located outside of the realm of the Christian belief system, often even as something not being part of any form of religion, but as a kind of very individual 'neutral spirituality' that is not linked to any faith or belief, or any religious institution (cf. Schweizer \& Noth 2017:211-226). That is, they see spiritual care as something different, almost opposed to pastoral care.

Others see spiritual care as an overarching term that includes pastoral care and the care for those who have no affiliation with a Christian church or are not linked to any form of community where they share the same belief. They predict that in some years, pastoral care will become a sub-discipline of spiritual care.

Some even say that in some years they will call their own work spiritual care, although they will not change what they do, nor the way they do it. They assume that their clients will prefer the term spiritual care to pastoral care because it conveys to be a care beyond the ties of confessions and denominations and less linked to the main line churches. It shows that the pastors are reluctant to admit that they are part of the body of the church. They fear to be looked at as taking part in an old fashioned, outdated, rigid institution that was responsible for suppressive structures fostering feelings of guilt and shame (Schweizer \& Noth 2017:225).

'Spiritual care' seems to be a term that is less burdened with traditions, attributions and transferences. It gives the impression of being 'more open' and less connected with 
institutionalised forms of religion. The term spiritual care seems to be more adequate, more fit for a pluralistic society and its individual, multicultural and interreligious perspectives and challenges. What does this tell about the perceptions pastoral care have and about the needs they see in their professional field?

- They see the growing plurality in the field of religions, of faiths and beliefs and their own difficulty to meet these diverse needs they are confronted with.

- They see many people who have no religious affiliation or are not able to draw hope or consolation from it. Nevertheless, these people see themselves as spiritually interested.

- They see people who have no religious affiliation at all and are not spiritually interested, but have to cope with existential crises or feel threatened by personal illness or loss.

By using spiritual care instead of pastoral care as their job description, the pastoral care takers want to convey that they feel responsible not only for Christians but for other believers and members of other religious groups as well. At the same time they want to point out that they want to offer an open and helpful conversation and do not want to force their clients into any form of belief or confession.

At the same time the argumentation of the pastoral care takers shows that they perceive their clients as very skeptical and suspicious towards all kinds of religious institutions and their representatives. The reaction of the pastoral care taker to this is to leave their own religious and organisational affiliation in indifferent vagueness in order not to provoke resistance or rejection.

But what if the perception of the pastoral care takers is tainted by their own counter transferences? What if the Christian pastoral care takers' relations towards their own churches are also coloured by a certain ambiguity? What if the care takers themselves are insecure and helpless when they face people with other beliefs or people who get along without any belief at all?

\section{Helpful perspectives from outside the realm of church and theology}

For a long time in German-speaking countries and in many other European countries, serious academic psychotherapy and psychoanalysis have not dealt with religion and spirituality at all. Psychotherapists did not attend to their own spirituality during their therapeutical training, nor was the subject of spirituality or religious affiliation of the client touched during treatment. This was especially difficult when psychotherapists worked in regions where the level of religious affiliation was high and clients and patients dealt with positive or negative consequences of their religious beliefs and involvements.

During the last years it was mostly theology that dealt with psychological questions and perspectives to learn from the psychological perspective for pastoral care, to understand the development of faith during the life cycle or to understand the consequences of destructive forms of belief. Different from the research in the United States, the positive effects of faith on mental health or on resilience were not in the focus of interest.

Therefore, the book on 'psychotherapy and spirituality' of the psychologist, Michael Utsch, and the psychiatrists Raphael Bonelli and Samuel Pfeiffer published in a series of medical books which was something new and long waited for (Utsch, Bonelli \& Pfeiffer 2014).

Theauthors describe that in the community of psychotherapists there is a large tendency not to deal with any form of religion or belief. Many therapists only have unease when it comes to religion. Others harbor a strong prejudice against religion. This is often a rather implicit opinion in the community of psychotherapists. But some do not hesitate to be outspoken on this subject. Bonelli tells about a colleague in Vienna who spoke in a public discussion saying that to him religious beliefs are a form of magical thinking, even a 'Micky Mouse thinking'. After three months of therapy with him, clients would not speak about religion any more even if they came to him as strong believers (Utsch et al. 2014:50). Bonelli states that even colleagues who think of themselves to be tolerant and open minded develop strong feelings of counter transference when it comes to the field of religion. For Bonelli this is only partly because of strong anti-religious tendencies of the forefathers of psychotherapy such as Sigmund Freund, who was strongly influenced by Ludwig Feuerbach. For him the reasons lie in the academic tradition of enlightenment that cannot accept religion within its world because it is considered to be a flaw on the way to complete enlightenment. For psychotherapists and many other academics in Europe the image of modern men cannot tolerate the existence of the supra-natural or transcendent. Religion goes against the narcissistic ideal of the enlightened academic and provokes strong feelings, going along with sound prejudices and little knowledge about religion (Utsch et al. 2014:51).

What advice do Bonelli, Utsch and Pfeiffer give? Firstly, they ask their colleagues not to pathologise too quickly when being confronted with religious beliefs. Like any other worldview, religious beliefs should be treated with tolerance and respect.

But even more, Bonelli and his colleagues suggest that psychotherapists instead of trying to act from a 'neutral' point of view - which is in fact never neutral - they should analyse very closely their own system of values, of cultural inheritances and of worldviews and beliefs.

\section{Offering Seelsorge/pastoral care in secular and multi-religious settings}

In Europe pastors and other religious care takers are academically educated at the public universities where the ideal of enlightenment is still in place and the prejudices against 
religion are still strong. For students of theology it is often not easy when mingling with students from other faculties. Often they have to defend themselves against the questions why there is a faculty of theology within an university. It is not only on the undergraduate level that academics harbor prejudices and/or are ignorant in the field of theology.

In Germany, Switzerland and Austria students of theology have their vocational training in the realm of the churches after graduation. From then on, many pastors spend most of their worklife with people within the church, in parishes and congregations. They only work outside of the churches when teaching religion in public schools or when working as chaplains in public hospitals. As I mentioned above, the statechurch-treaty obliges the pastors to supply religious education in public schools and pastoral care in public institutions.

It is in these public spheres that pastors would rather offer spiritual care than (Christian) Seelsorge/pastoral care. When offering (Christian) Seelsorge/pastoral care you have to deal with all the transferences churches and religion evoke. Many people who are part of a congregation will forge a trusting relationship very quick, others have to deal with memories that make it difficult to enter into a deep conversation. Others who had few contact with religion may be interested or do not have any interest at all.

Spiritual care seems to be a good way to avoid all these traps and transferences. As a spiritual care taker you do not identify with any tradition or religion. The term spiritual care leaves in the vague where you come from. In German language, spirituality is a kind of mild dose of religion that does not hurt or evoke rejection. Being sarcastic you could say that spiritual care represents a kind of 'neutral' form of care that some pseudo-enlightened academics might prefer to pastoral care when they happen to end up in a hospital.

But like the pseudo-enlightened academic who is not neutral in his worldview, the spiritual care giver is even less free of personal convictions and traditions. Instead of trying to cheat by not naming who you are and where you come from, (Christian) Seelsorger/pastoral care takers have to face the challenge to be open about their Christian background without being defensive when they meet people not believing at all (and looking down on them) or having a different faith that is not compatible with their faith.

\section{Epilog: Times are changing}

The humanistic turn in pastoral care and counselling taught pastors to listen to their clients, to learn to understand and to speak in the language and into the contexts of their clients.
In times of diversity and religious plurality, the Christian Seelsorger/pastoral care takers should not try to lower their profile or to disguise their identity. It is rather a time to be open about one's own identity, that is that Seelsorge/pastoral care is an important part of the tradition of Christian churches. It is only by showing who you are that others are able to communicate with you. The post-colonialist, Homi Bhabha, calls this a third space (Bhabha 1997:123-148). It is not me and not you, but an intermediate space of conversation between the pastoral care taker and the one in need.

I can see some medical contexts where the term 'spiritual care' might be helpful to support the argument that spiritual needs have to be taken into account as well. For the German context I see many reasons to stick with our wonderful German term 'Seelsorge', because the term itself represents the openness that is connected to the word 'soul', with the specific Christian meaning of 'Seelsorge' that places Seelsorger/ pastoral care takers within a specific tradition.

\section{Acknowledgements Competing interests}

The author declares that she has no financial or personal relationships which may have inappropriately influenced her in writing this article.

\section{References}

Bhabha, H., 1997, 'Verortungen der Kultur', in E. Bronfen, M. Benjamin\& T. Steffen (eds.), Hybride Kulturen. Beiträge zur anglo-amerikanischen Multikulturalitätsdebatte, pp. 123-148, Stauffenburg-Verlag, Tübingen.

Evangelische Kirche in Deutschland (EKD), (Hg.),2015, V. Kirchenmitgliedschaftsstudie Engagement und Indifferenz. Kirchenmigliedschaft als soziale Praxis, Hannover.

Hess, W. \& Nagel, B., 2017, KSA- interreligiös. Reflexionen über einen (un)gewöhnlichen Seelsorge-Kurs, Evangelische Kirche, Hessen und Nassau.

Klessmann, M., 2008, Seelsorge. Begegnung, Begleitung, Lebensdeutung im Horizont des christlichen Glaubens. Ein Lehrbuch, Neukirchener Verlag, Neukirchen-Vluyn.

Nauer, D., 2015, Spiritual care statt Seelsorge, Kohlhammer, Stuttgart.

Puchalski, C., Ferrell, B., Virani, R., Otis-Green, S., Baird, P., Bull, J., Chochinov, H., Handzo, G., Nelson-Becker, H., Prince-Paul, M., Pugliese, K., Sulmasy, D., 2009, 'Improving the quality of spiritual care as a dimension of palliative care: the report of the Consensus Conference', Journal of Palliative Medicine 12 (10), 888-904.

Rizzuto, A.-M., 1979, The birth of the living God. A psychoanalytic study, Chicago University Press, Chicago, IL.

Roser, T., 2007, Spiritual care - Ethische, organisationale und spirituelle Aspekte der Krankenhausseelsorge. Ein praktisch-Theologischer Zugang, Kohlhammer, Stuttgart.

Saunders, C., 1988, 'Spiritual pain', Journal of Palliative Care 4(3), 29-32.

Schweizer, E. \& Noth, I., 2017, 'Spiritual care aus der Sicht von Seelsorgenden', in I. Noth, G. Wenz \& E. Schweizer (eds.), Seelsorge und Spiritual Care in interkultureller Perspektive [Pastoral and spiritual care across religions and cultures], pp. 211-225, Vandenhoek \& Ruprecht, Göttingen.

Utsch, M., Bonelli, R.M. \& Pfeiffer, S., 2014, Psychotherapie und Spiritualität. Mit existentiellen Konflikten und Transzendenzfragen professionell umgehen, Springer, Berlin.

Walther, T., 2009, 'Individualization - Migration - Globalization: A protestant perspective on interfaith spiritual caregiving in the hospitals in Switzerland', in D. Schipani\& L.D. Bueckert (eds.), Aninterfaithspiritual care. Understanding and practices, pp.259-278, Pandora Press, Kitchener, ON (in Collaboration with SIPCC Society for Intercultural Pastoral Care and Counceling). 